\title{
HERE BE DRAGONS \\ VOORGESCHIEDENIS EN ONTSTAAN VAN ADVENTURE GAMES
}

Inleiding

\begin{abstract}
'At the end of the Middle Ages, Europe's thousand year sleep - or perhaps thousand year germination - between antiquity and the Renaissance, wondrous things were happening. High culture, long dormant, began to stir again. The spirit of adventure grew once more in the human breast. Great cathedrals rose, the spirit captured in stone, embodiments of the human quest for understanding. But there were other cathedrals, cathedrals of the mind, that also embodied that quest for the unknown. They were maps, like the fantastic, and often fanciful, Mappa Mundi - the map of everything, of the known world, whose edges both beckoned us towards the unknown, and cautioned us with their marginalia - "Here be dragons." "1
\end{abstract}

Aan het begin van de eenentwintigste eeuw is onze wereld grotendeels geëxploreerd. Wanneer wij de sensatie, de verwondering en het gevaar van de oude ontdekkingsreizen willen beleven moeten we onze toevlucht nemen tot boeken, films en pretparken. Of we spelen een spel op de computer, bij voorkeur een adventure game. Het gevoel dat, met name de eerste generatie, adventure-spellen wist op te roepen komt heel dicht bij de spanning die de vroegere ontdekkingsreizigers moeten hebben gevoeld. In een traditioneel adventure game betreedt de speler namelijk ook een onbekende labyrintische ruimte die stap voor stap verkend moet worden, zonder te weten welke draken er op de loer liggen. Het grote verschil met de oorspronkelijke Mappa Mundi is dat de voor jou onbekende wereld vooraf is ontstaan in de geest van een moderne griot. Een meesterverhalenverteller die je stap voor stap meezuigt in zijn immersieve wereld zodat de werkelijkheid om je heen met elke stap die je neemt verder vervaagt.

De adventure game is in de literatuur vaak een onderbelicht speltype. ${ }^{2}$ Dit heeft mijns inziens vier oorzaken. Allereerst is het een type spel dat in de beginjaren vooral op grotere computers van universiteiten en andere instellingen van hoger onderwijs gespeeld werd. Pas begin jaren tachtig vond het zijn weg naar de eerste personal computers (zoals de Apple ir). ${ }^{3}$ Voor arcadehallen 
waren adventure games niet interessant omdat ze tot I979 alleen uit tekst bestonden. ${ }^{4}$ In historische overzichten, die vaak op hardware gebaseerd zijn, worden ze daarom vrijwel nooit genoemd tot die tijd. Vervolgens was dit type spel in het Westen tot midden jaren negentig vooral op thuiscomputers populair. In Japan wordt het wel (en veel) gespeeld op spelcomputers, maar deze spellen, zoals ZE LDA (Nintendo, eerste spel i986) en F I NAL FANTASy (Square, eerste spel I987), werden hier pas echt populair met de komst van de GameBoy (I989) en de Playstation (versie I in I995 en versie II in 2000). De overgang van het toetsenbord naar de muis als primair invoerapparaat was ook de oorzaak van een fundamentele verandering: de overgang van tekst naar beeld. De fans vonden deze overgang niet altijd even gelukkig en velen haakten af, zodat het adventure spel in de jaren negentig in een crisis belandde. Tenslotte zijn er enkele game researchers, zoals Jesper Juul, die pure adventure games niet als computerspel categoriseren omdat narrativiteit en interactie in hun ogen niet samengaan. ${ }^{5}$

In dit artikel wil ik dieper ingaan op dit type computerspel, de adventure game, ook wel interactieve fictie genoemd. Ik zal uitgebreid stilstaan bij de twee culturele fenomenen die aan dit type computerspel voorafgingen: het werk van J.R.R. Tolkien en het rollenspel DU NG EO N S AN D D RAGons. Hoewel $\mathrm{ik}$ me beperk tot een bepaald type computerspel is dit type nog te omvangrijk om het uitputtend te kunnen behandelen. Ik zal me daarom beperken tot de vroegste geschiedenis van de adventure game en tot spellen die gespeeld werden (en worden) op personal computers. ${ }^{6}$ Daarnaast wil ik kort ingaan op de fascinatie voor de Middeleeuwen die vooral in dit type computerspel naar voren komt.?

\section{Het hoe, wat en waarom van adventure games}

Hoewel er een duidelijk verschil is tussen de eerste adventure spellen die uitsluitend uit tekst bestonden en die ook met behulp van tekstuele opdrachten gespeeld werden, en de latere grafische adventures, kan toch in zijn algemeenheid gesteld worden dat een adventure game een interactief verhaal is. Daarom wordt dit soort spellen ook wel aangeduid met de term interactieve fictie. In een adventure spel wordt de hoofdrolspeler voor een bepaald 'probleem' gesteld (het vinden van een schat, het ontmaskeren van een moordenaar, het hervinden van de eigen identiteit, enzovoort) en moet hij of zij door het oplossen van (veelal logische) puzzels en het vinden van aanwijzingen en voorwerpen het probleem oplossen. De speler van het spel doet dit, afhankelijk van het spel, in 'eigen persoon' als ik-figuur, of bestuurt de hoofdrolspeler in het spel en speelt aldus in de derde persoon. Het 'zelf kunnen meespelen' in een fictief verhaal vormt de belangrijkste aantrekkingskracht van de traditionele adventure zoals ook blijkt uit deze bijdrage aan de Wikipédia: 


\begin{abstract}
'Un jeu d'aventure, du point de vue du joueur, est une œuvre de fiction interactive, soit bien plus qu'un jeu vidéo. Cette phrase donne l'essence de tout ce qu'il y a à dire sur les aventures. Tout d'abord, une fiction. Comme un film, un roman ou une bande dessinée, une aventure raconte une histoire.

Interactive, car contrairement à un film, un roman ou une bande dessinée où l'on reste prisonnier de la linéarité de l'intrigue, on interagit dans un jeu d'aventures avec l'environnement. Du fait de son caractère narratif, le jeu d'aventure se rapproche de ce qui fait la substance même des œuvres d'art'.
\end{abstract}

Naast traditionele adventure games bestaan er ook Role Playing Games (R PG's), dit zijn adventures waarbij de speler deel uitmaakt van een groep die samen het avontuur tot een goed einde moet brengen. In offline role playing games is de speler hetzij de leider van de groep (zoals Robin Hood), hetzij een van de mogelijke speelbare karakters (Aragorn, Legolas, Gimli). Bij online adventures en role playing games, zoals Multi User Dungeons (M U D's) ${ }^{9}$ en Massively Multiplayer Role Playing Games (M M RPG's), is het gebruikelijk dat de speler zelf een spelkarakter samenstelt. In dit soort spellen moeten ook wel missies uitgevoerd en problemen opgelost worden, maar de nadruk ligt toch vaker op karakterontwikkeling en het instandhouden van de illusie en de fantastische wereld. Met de komst van Lara Croft in het spel том в RAIDE R (Eidos Interactive) in I996 breekt een nieuw subtype van het adventure spel definitief door op de personal computer: het action adventure. ${ }^{\text {Io }}$ In deze spellen is behendigheid van de hoofdpersoon (en knopvaardigheid van de speler) een wezenlijk onderdeel van het spel en kan het avontuur zonder deze vaardigheid niet tot een goed einde gebracht worden. Een variant op de action adventure game is de stealth action game, waarbij sluipen en het zich verstoppen achter obstakels een beter resultaat opleveren dan harde actie. Op de PC is dit type vooral bekend van TOM CLANCY'S SPLINTER CELL (Ubisoft Entertainment, 2003), maar werd al eerder geïntroduceerd in het spel thinf: THE DARK PROJECT (Looking Glass Studios, I998).

Hoewel veel moderne adventure games ver verwijderd lijken van de eerste spellen, zijn de wezenlijke elementen van het speltype nog altijd herkenbaar. Deze elementen vinden hun oorsprong buiten het computerspel, in de fictie van J.R.R. Tolkien en het rollenspel DUNGEONS AND DRAGONS.

\title{
Tolkien en de oorsprong van het fantasy genre
}

Dankzij de recente spectaculaire verfilming van Tolkiens The Lord of the Rings (I954) door Peter Jackson (New Line Cinema, 200I-2003), staat het werk van Tolkien weer volop in de belangstelling. Dit heeft onder andere geleid tot nieuwe computerspellen over The Lord of the Rings en The Hobbit (I937); voor een groot deel gebaseerd op de film, maar ook naar aanleiding van het oorspronkelijke werk. Eigenlijk moeten we spreken van de zoveelste opleving van de Tolkien- 


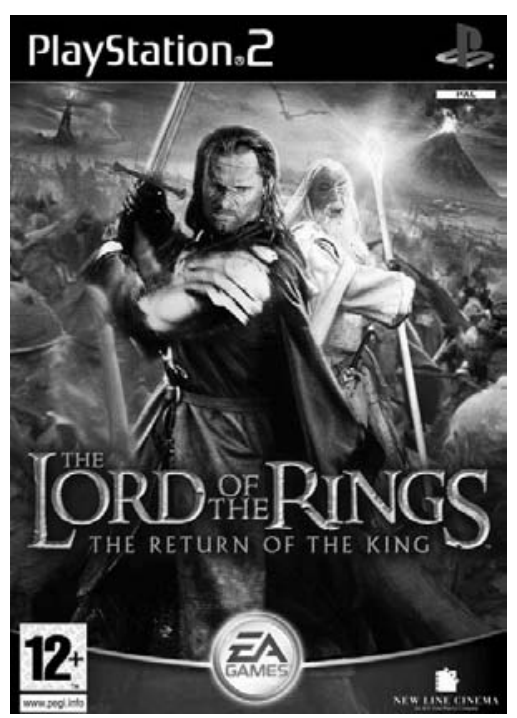

THE LORD OF THE RINGS. THE RETURN OF THE KING (Electronic Arts, 2003) hype, want sinds het verschijnen in Amerika van de eerste bootleg pockets van The Lord of the Rings in I965 is zijn werk door elke nieuwe generatie herontdekt en telkens in een nieuwe culturele context ingepast.

Tolkiens inwerking op de populaire cultuur van de twintigste eeuw is onmiskenbaar. Zijn invloed is terug te vinden in alle populaire media: het (strip)boek, de tv, de bioscoop en het computerspel. Eén van de bekendste fantasy schrijvers van de twintigste eeuw, Terry Pratchett, verwoordt Tolkiens invloed op het fantasy-genre als volgt: 'Tolkien influenced everyone that came after. He set his stamp on the genre so heavily that there is an echo of it even now'. .' Anders dan algemeen aangenomen wordt is Tolkien niet de eerste vertolker, noch de uitvinder, van het fantasy genre. In de Victoriaanse tijd ontstond, onder invloed van de industrialisatie en de expansie van GrootBrittannië tot koloniaal wereldrijk, een hernieuwde belangstelling voor het Britse verleden, met name voor de Middeleeuwen. We zien dit onder andere terug in de vele neogotische bouwwerken die opgetrokken werden door het nieuwe industriële kapitaal. In de kunsten overheerst het werk van de prerafaëlieten, een stroming die zocht naar een nieuw houvast, nu wetenschappelijke ontdekkingen de oude religieuze waarheden leken te ondermijnen. Een terugkerend thema in het werk van de prerafaëlieten zijn Britse mythen en legenden, met name de middeleeuwse Arthur-legenden. ${ }^{\text {I2 }}$

Eén van de leden van deze stroming, William Morris, is een veelzijdig talent (onder andere schilder, dichter en politicus). In onze eeuw is hij vooral bekend als graficus en ontwerper, en als grondlegger van de Arts and Crafts-beweging. Wat weinigen buiten Engeland weten is dat Morris de werkelijke grondlegger van het fantasy genre is. Net als andere prerafaëlieten was hij geïnteresseerd in de literatuur, sagen en legenden van de Middeleeuwen. Morris ging hierin verder dan de anderen. Zo vertaalde hij samen met Eirikr Magnusson Oud-Noorse gedichten, waaronder de Volsunga Saga. Net als Tolkien zag hij in de OudNoorse literatuur het ware culturele erfgoed van West-Europa. ${ }^{\text {I3 }}$ De Volsunga Saga vormde de literaire basis van zijn eigen gedicht Sigurd (I877) en zijn prozawerk Tale of the House of the Wolfings (I898). Dit soort 'historische' werken vormde de opmaat tot Morris' fantasy-verhalen waaronder The Wood beyond the World (I894) en The Well at World's End (I896).

De uitgangspunten voor Tolkiens werk zijn van een andere aard dan die van Morris. Tolkien betreurde, net als Morris, het gebrek aan een eigen homogene Engelse cultuurgeschiedenis. Als kind werd hij al gegrepen door West-Europese sagen en legenden waaronder het verhaal van Sigurd, ${ }^{\text {I4 }}$ en ook Morris' vertaling van de Volsunga Saga als diens House of the Wolfings behoorde tot Tolkiens favo- 
riete literatuur. ${ }^{15}$ Maar anders dan Morris wil Tolkien zich niet louter beperken tot de herintroductie van deze werken in het culturele bewustzijn van de Brit. Tolkien wilde meer, hij wilde Engeland zijn verloren cultuurgeschiedenis teruggeven:

'I had in mind to make a body of more or less connected legend, ranging from the large and cosmogonic, to the level of romantic fairy story(...) which I could dedicate simply: to England; to my country'. ${ }^{16}$

Door zijn werk als professor in de filologie was Tolkien niet alleen bekend met middeleeuwse literaire werken, maar verdiepte hij zich ook in de West-Europese taalgeschiedenis. Vanuit deze achtergrond redeneerde Tolkien dat, wanneer elke Germaanse taal een verwant woord voor dwerg (fantasiewezen) heeft, er dan niet alleen een gezamenlijk 'oerwoord' moet bestaan, maar dat daaraan ook een gezamenlijk 'oerbegrip' ten grondslag moet liggen. ${ }^{\text {I7 }}$ Omdat dergelijke woorden in context ontstaan zijn - zo redeneerde hij - moet het ook mogelijk zijn uit westerse mythen, sagen, legenden, volksverhalen en sprookjes het oorspronkelijke verhaal te herleiden en aldus de verloren gegane cultuurgeschiedenis te re-creëren. ${ }^{18}$ Strikt genomen zijn Tolkiens verhalen dus niet oorspronkelijk. In The Silmarillion (postuum verschenen in 1977) en The Lord of the Rings weet hij echter als geen ander de gegeven elementen samen te voegen tot een, in meerdere opzichten, episch en mythisch geheel. Of zoals zijn biograaf Humphrey Carpenter het samenvat:

'He [Tolkien] said he wanted to create a mythology for England. I don't think he did exactly that, but I think he rediscovered kinds of narrative with the power of the saga and the adventure story which had been lost from twentieth century English fiction'. ${ }^{\text {ig }}$

Tolkiens boeken hebben, zoals gezegd, de westerse populaire cultuur enorm beïnvloed. De hippiegeneratie riep om 'Gandalf as president' en de Engelse milieubeweging van de jaren negentig liet zich inspireren door Tolkiens liefde voor de natuur. Voor het ultieme medium van de laatste decennia van de twintigste eeuw, het computerspel, was Tolkiens inspiratie een doorbraak, zoals game-ontwerper Ian Livingston stelt:

'Then suddenly comes Tolkien. You got this world of contense gloom and danger and doom, all this disgusting creatures that he created out of his imagination. (...) he made us see a much darker, stronger, richly imagined world of fantasy, which had never been done before'. ${ }^{2 \circ}$

Vooral auteurs van de eerste generatie adventure en role playing games zijn schatplichtig aan het werk van Tolkien, waaronder Richard Garriott, de ontwerper van de legendarische U LTima serie (eerste deel I98I): ${ }^{2 \mathrm{I}}$ 
“"Three important events happened in I974," says Richard Garriott. "First, my sister-in-law gave me a copy of Lord of the Rings. Second, I discovered Dungeons \& Dragons. And third, I became acquainted with my first computer. In combination, these three events began a love affair with the computer that has continued to this day.",22

In geen enkel medium komt de door Tolkien gecreëerde wereld meer tot zijn recht en kan de grootste wens van menig Tolkien-fan in vervulling gaan: zelf deelnemen aan de ultieme fantasie die Middenaarde heet. En waar computerspellen zich voorheen beperkten tot behendigheidsoefeningen, vaak in de vorm van herkenbare sporten, is het Tolkiens imaginaire wereld die niet alleen een nieuwe omgeving en nieuwe karakters inspireert, maar die ook voor het eerst een - zij het in het begin beperkt - verhaal aan de spelwereld toevoegt.

\section{DUNGEONS AND DRAGONS; van tinnen soldaatjes en een cultureel fenomeen}

'A friendly unicorn named Alabern lives in the woods near your town. With a touch of its horn, Alabern heals wounded people who come to it for help. Now a woodcutter has come to town with terrible news. Evil goblins have captured the unicorn and taken it away... ${ }^{23}$

Dit is een van de vele verhalen waarmee een avontuur in het spel DUNGEONS AND DRAGONS begint. DUNGEONS AND DRAGONS is een role playing game ${ }^{24}$ dat zich voornamelijk afspeelt in de fantasie van de spelers. Anders dan bij het naspelen van historische veldslagen of Life Action RPG's (LAR P's), spelen DU NGEONS AND DRAGONS rollenspellen zich af in studentenkamers of soortgelijke ruimtes. De deelnemers bestaan uit een spelleider (the dungeon master) en een groep spelers. Hoewel de deelnemers niet in kostuum hoeven te verschijnen, moeten ze wel 'in karakter' verschijnen, dat wil zeggen dat ze tijdens het spel hun dagelijkse identiteit afleggen en een rol in het spel aannemen. De personages in klassieke D\& D spellen vertegenwoordigen een bepaald ras zoals mens, elf of dwerg. Vervolgens kan men kiezen uit verschillende rollen zoals dief, vechter of magiër. De combinatie van beide bepaalt de basisvaardigheden van een speler. Een groep spelers moet met behulp van deze vaardigheden, die in de loop van meerdere spellen uitgebreid kunnen worden, een avontuur aangaan en tot een goed einde brengen. Of het avontuur slaagt, is mede afhankelijk van het lot (in de vorm van meerzijdige dobbelstenen). De spelleider geeft daarbij aanwijzingen. Een goede spelleider kan zelf avonturen verzinnen, maar avonturen kunnen ook gekocht worden in de vorm van complete spellen of spelboeken. Het is gebruikelijk dat een speler over meerdere spellen zijn of haar karakter behoudt waardoor nieuwe vaardigheden geleerd en bestaande vaardigheden verbeterd kunnen worden. Een essentieel onderdeel van DUNGEONS AND DRAG- 
ons is dat spelers alleen door onderlinge samenwerking (de combinatie van persoonlijke vaardigheden) de hindernissen die ze tijdens het avontuur tegenkomen (gesloten deuren, verborgen gangen, vijanden zoals orcs of boosaardige magiërs, enzovoort) kunnen overwinnen. De huidige (Massively Multiplayer) Role Playing Games zijn feitelijk computerversies van DUNGEONS AND DRAGONS, en ook kaartspellen als MAGIC vinden hun oorsprong in dit spel.

Het spel DUNGEONS AN D DRAGONS is voortgekomen uit het (na)spelen van (bekende) veldslagen (het zogenaamde Kriegspiel of wargaming). Eerst gebeurde dit voornamelijk in een militaire setting, maar al snel werd het ook een populair tijdverdrijf van de burgerij. Een bekende wargamer was de Engelse science fiction schrijver H.G. Wells, bekend van The War of the Worlds (I894) en The Time Machine (I895). Wells was een zodanige fan van dit oorlogsspel dat hij in I9I3 zelfs een boek met spelregels publiceerde: Little Wars. ${ }^{25}$ Traditioneel worden Kriegspiele uitgevochten met behulp van tinnen soldaten en een in miniatuur nagebouwd slagveld. Zowel in de negentiende als de twintigste eeuw groeit de populariteit van deze spellen en overal ter wereld ontstaan clubs zoals de International Federation of Wargamers ( $\mathrm{IFw}$ ) die rond ${ }_{19} 63$ in Amerika wordt opgericht. ${ }^{26}$ Eén van de grondleggers van deze club is E. Gary Gygax. ${ }^{27}$ Omdat Gygax erg geïnteresseerd was in de geschiedenis van de Middeleeuwen, richtte hij al snel een eigen subdivisie op met de naam Castle and Crusade Society. In deze groep worden veldslagen uitgevochten gebaseerd op middeleeuwse wapens en krijgskunde. Blijkbaar kent het virtueel vechten met pijlen, hellebaarden en katapulten zijn grenzen, want het aantal groepsleden nam gestaag af. Om de interesse van de leden vast te houden besloot Gygax, geïnspireerd door het werk van Tolkien, Fritz Lieber en Robert E. Howard, ${ }^{28}$ fantasy elementen, zoals magiërs, in de regels van het spel in te bouwen. Dit bleek een gouden greep te zijn. Het 'nieuwe' spel waarvan de regels onder de naam Chainmail: Rules for Medieval Miniatures in 197I officieel werden uitgebracht, was een groot succes. Maar in principe was het nog altijd een Kriegspiel: de nadruk ligt op de campagne en niet op het rollenspel. Dat verandert wanneer Gygax in I97I Dave Anderson ontmoet. Anderson had in 1970 met behulp van Gygax' spelregels een scenario geschreven waarbij een groep avonturiers een vesting moest binnendringen. In Andersons spel ligt de nadruk op het avontuur en op de individuele karakters van de spelers. Samen met Gygax schreef hij meer scenario's waarbij de nadruk steeds meer op het exploreren van donkere kerkers in een fantastische wereld, en op de ontwikkeling van de karakters kwam te liggen. Het spel verhuisde daarbij al snel van miniatuur naar papier omdat het steeds moeilijker werd de complexe ondergrondse gewelven waarin de avonturen zich afspeelden na te bouwen: DUNGEONS AND DRAGONS was geboren. ${ }^{29}$

De populariteit en cultstatus van het spel DUNGEONS AND DRAGONS is vele malen vereeuwigd in andere media zoals boeken, televisieseries en films. ${ }^{30} \mathrm{Net}$ als met de representatie van de latere computerspellen gaat het hierbij meestal om een negatief commentaar dat vooral de mening van de bezorgde volwasse- 
nen vertolkte zoals in de tv-film MAZES AND MONSTERS (Warner Studios) uit I982 met Tom Hanks in de hoofdrol. ${ }^{31}$ Hanks speelt een tiener, Robbie Wheeling, die vanwege zijn obsessieve spelen van het spel DUNGEONS AND DRAGONS door zijn ouders naar een andere school wordt gestuurd waar hij zich, naar zij hopen, weer op zijn lessen zal concentreren. Op de nieuwe school vindt hij al snel aansluiting bij een groep leerlingen die ook fans van het spel zijn. Om hun avontuur realistischer te maken besluit de groep een nabijgelegen grottencomplex als spelachtergrond te gebruiken. Tijdens hun tocht ondergaat Robbie een psychose waardoor hij geestelijk altijd in een imaginaire middeleeuwse wereld zal verblijven. De inhoud van de tv-film heeft veel weg van het eerste publieke schandaal rond DU NGEON S AN D DRAGons uit I979, toen de Amerikaanse student James Dallas Egbert i i verdween. William Dear, de privédetective die met het onderzoek belast was concludeerde dat Egbert verdwenen was tijdens het spelen van DUNGEONS AND DRAGONS en dat hij vermoedelijk niet meer in leven was. In werkelijkheid was Egbert na een mislukte zelfmoordpoging gevlucht en toen hij een maand ${ }^{32}$ later naar huis terugkeerde besloot de familie aan de werkelijke redenen van zijn verdwijning (homosexualiteit, psychische nood en een drugsverslaving) geen ruchtbaarheid te geven. Hierdoor was de slechte naam van DUNGEONS AND DRAGONS in de publieke opinie gevestigd en bleef de versie van Dear, die hij ook beschreef in het boek Dungeon Master: The Disappearance of James Dallas Egbert III (I984), overeind. Het gevolg was een ware kruistocht tegen het spel, gebaseerd op dit, en andere, opgeklopte sensatieverhalen, zonder dat iemand de moeite nam te verifiëren wat de werkelijke oorzaak van de gebeurtenissen was. Zo is ook de voorstelling van DUNGEONS AND DRAGON S in MAZES AN D MONSTERS weinig reëel. Dit leidde indertijd tot protesten van de fans van het genre, terwijl de niet-ingewijden hun ergste vermoedens bevestigd zagen. ${ }^{33}$

\section{ADVENTURE en ZORK, de geboorte van text adventures}

Tolkiens werk beïnvloedde de bedenkers van DUNGEONS AND DRAGONS en D\&D inspireerde op zijn beurt weer het eerste avonturenspel ADVENTURE ${ }^{34}$ (I972, ook bekend onder de naam ADVENT of ColosSAL CAVE ADVENTURE). De bedenker van het spel, Will Crowther, was aangesteld als programmeur bij de firma Bolt Bernak and Newman. In zijn vrije tijd was Crowther, samen met zijn vrouw Pat, een fanatiek speleoloog. De exploratiedata die beiden op hun ontdekkingstochten verzamelden werden, met behulp van de computer, omgezet in plattegronden, die Crowther, geïnspireerd door de prachtige grotten die hij gezien had, voorzag van sprekende namen zoals 'The Hall of the Mountain King'. Rond I972 liep Crowthers huwelijk echter stuk. Omdat de speleologie een gezamenlijke hobby was, stopte hij met zijn onderaardse expedities. Hierbij betreurde hij vooral dat hij zijn liefde voor de speleologie niet aan zijn dochters kon door- 
geven. Daarom besloot hij uiteindelijk een computerspel voor hen te maken gebaseerd op de in kaart gebrachte expedities:

'Also the caving had stopped, because that had become awkward, so I decided I would fool around and write a program that was a re-creation in fantasy of my caving, and also would be a game for the kids, and perhaps some aspects of the Dungeons and Dragons that I had been playing'.35

Het spel moest niet alleen leuk zijn, maar ook toegankelijk voor beginnende computergebruikers. Daarom bedacht Crowther een 'vertaalprogramma' zodat het spel opdrachten in natuurlijke taal kon verwerken..$^{36}$ De speler hoefde dan niet eerst een set besturingsopdrachten te leren. Dat het spel alleen uit tekstbeschrijvingen bestond en geen grafische elementen bevatte kwam doordat het gespeeld werd op een multi-user computer. De speler beschikt daarbij niet over een eigen systeem maar is verbonden met de centrale computer, waardoor alleen korte opdrachten kunnen worden ingevoerd. Schermen die de uitvoer weergeven zijn in I972 een zeldzaamheid (zeker privé), de uitvoer verloopt in de regel via een printer (zoals bij een telex-machine).

In Crowther's originele versie van ADVE NTU R E ligt de nadruk op de speleologie. Het grottencomplex lijkt erg op de oorspronkelijke Mammoth Cave en de beschrijvingen komen overeen met de werkelijkheid. Het virtuele grotstelsel is redelijk complex, zodat de speler geruime tijd bezig is om het in kaart te brengen. Het spel bevat echter slechts vijf schatten, er wordt geen score van de vorderingen bijgehouden, de gevaren die de ontdekkingsreiziger tegenkomt zijn natuurlijke gevaren, zoals de slang, en veel termen die gebruikt worden komen uit de geologie. ${ }^{37}$

Crowthers dochters waren enthousiast en het spel vond al snel zijn weg naar vrienden en bekenden. Uiteindelijk stond het spel op vrijwel elke campuscomputer in Amerika. Zo belandde het ook op de computer van het laboratorium voor kunstmatige intelligentie van de Stanford University, waar Don Woods het in 1976 ontdekte. Hij vond het een prachtig spel maar wilde het graag uitbreiden. Met toestemming van Crowther, en sterk beïnvloed door The Hobbit (dwergen, draak, vulkaan) en The Lord of the Rings (de passage door de mijnen van Moria), bouwde Woods het computerspel uit. Het aantal schatten verdriedubbelde, nu werd wel een score van de vorderingen bijgehouden (met een maximum van 350 punten) en het grottencomplex werd uitgebreid met fictieve ruimten met fantasy elementen en namen (zoals de Troll Bridge). De nadruk lag nu niet meer op het exploreren, maar op het oplossen van puzzels en raadsels, het vinden van de schatten en het behalen van de maximale score, elementen die nog altijd bepalend zijn voor het speltype.

ADVENTURE ${ }^{38}$ speelt zich, zoals gezegd, grotendeels af in een onderaards labyrint. Het begint allemaal heel onschuldig met de woorden: 


\section{'At End of Road}

You are standing at the end of the road before a small brick building. Around you is a forest. A small stream flows out of the building and down a gully'.

In de oorspronkelijke versie was er verder geen uitleg, geen backstory, zoals nu in de meeste computerspellen gebruikelijk is. ${ }^{39}$ Maar omdat het in Crowthers versie om een exploratietocht door grotten ging was verdere uitleg ook niet nodig: het is logisch dat je begint met het verzamelen van objecten die van pas komen bij een zoektocht door grotten, zoals een lamp of een andere draagbare lichtbron. Door rond te lopen (door middel van opdrachten als north, south, east, west, down en up die afgekort kunnen worden tot n, s, e, enzovoort) vind je het veiligheidsrooster waarmee de ingang van de grotten afgesloten is en als je de sleutel uit het gebouwtje aan het begin meegenomen hebt, kun je het rooster openen. Omdat het spel enkel uit tekst bestaat wordt het al snel duidelijk dat een plattegrond op papier onmisbaar is om verdwalen te voorkomen. Vrijwel iedere speler van adventure games heeft daarom nog stukken ruitjespapier met daarop de plattegrond van een gespeeld spel. ${ }^{40}$ Opmerkelijk is natuurlijk dat op deze manier het in kaart brengen van de eigenlijke grotten uit de werkelijkheid automatisch gesimuleerd wordt.

Door de toevoegingen van Woods werd het vinden van de juiste oplossing voor een probleem een stuk moeilijker. Op zich zijn de puzzels nog redelijk logisch, bijvoorbeeld dat je een kooi nodig hebt om de vogel mee te nemen. Maar waarom de vogel bang is voor de staaf, wordt niet duidelijk. Een andere essentiële opdracht is save, niet alleen om te voorkomen dat bij elke sessie het spel weer helemaal vanaf het begin gespeeld moet worden. Ook omdat er, net als in latere adventure games, addertjes onder het gras zitten. Omdat je, in het spel, soms je handen vol hebt is het nodig om voorwerpen niet alleen op te pakken, je

Voorbeeld van een eigengemaakte plattegrond

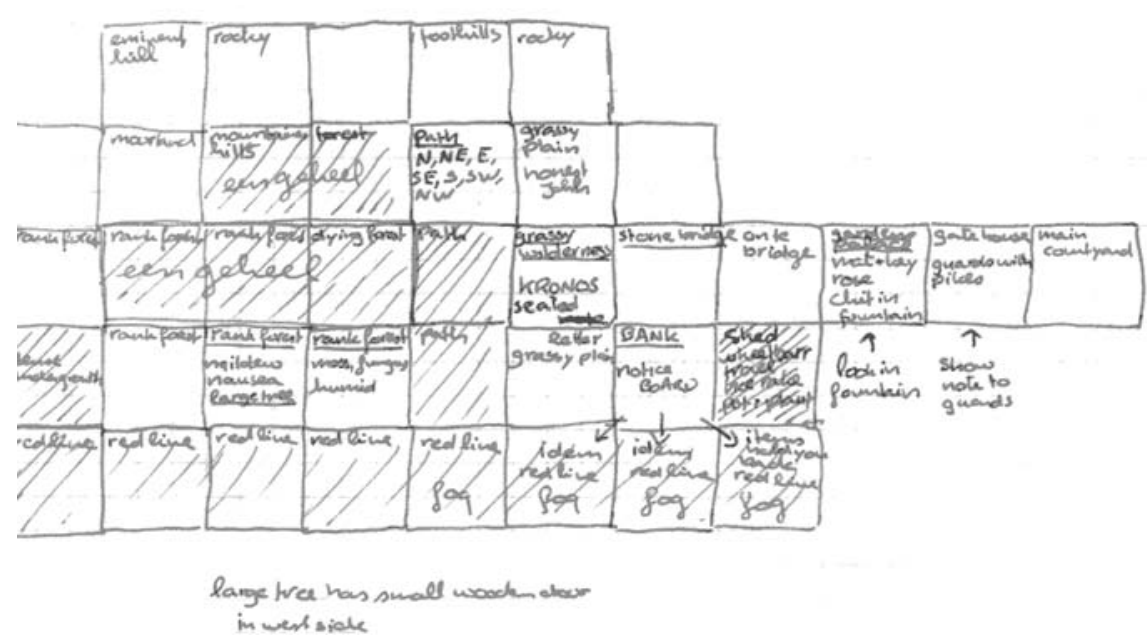




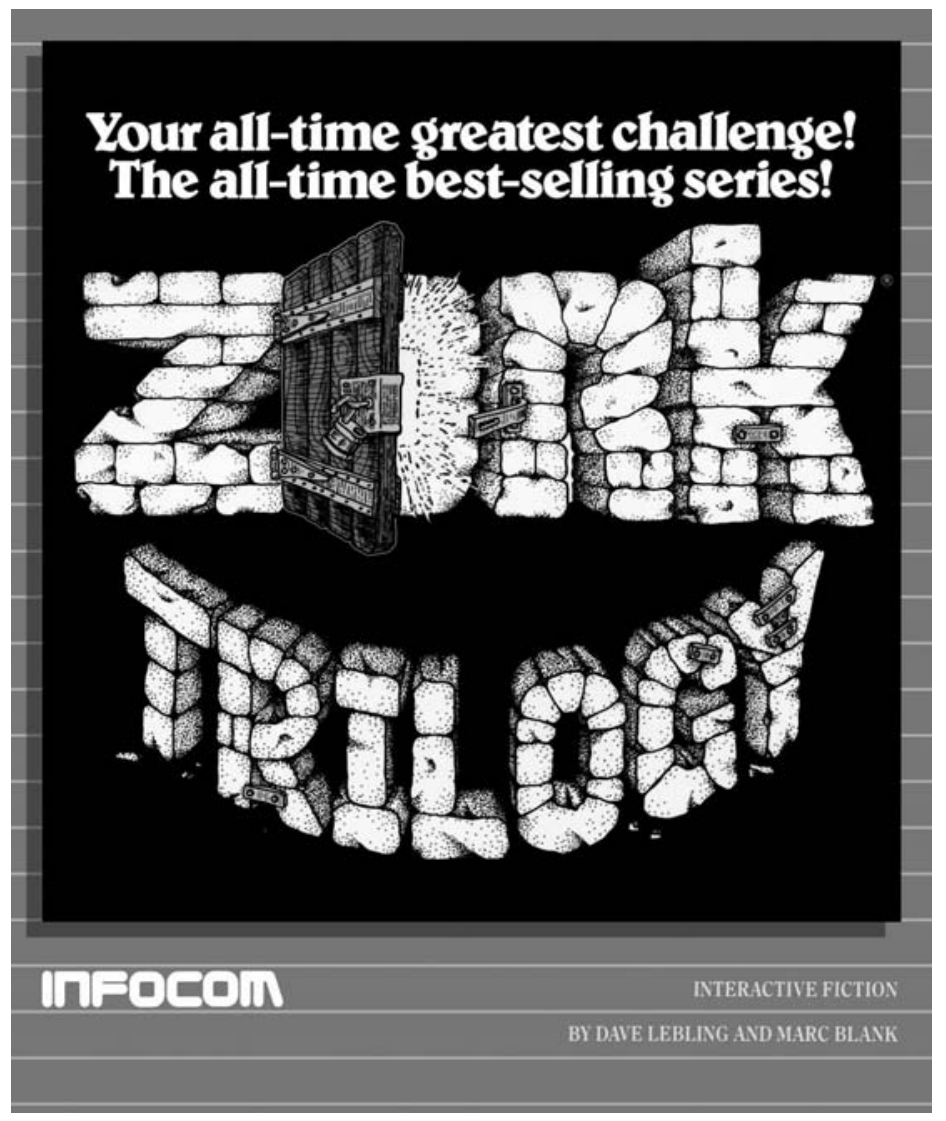

moet ze ook weer uit handen kunnen geven. Dat gebeurt gebruikelijk met de opdracht drop. Letterlijk betekent dit natuurlijk dat je iets laat vallen, dus moet je ook niet verwonderd zijn wanneer de kostbare Ming-vaas aan stukken gaat als je zegt drop vase. Dit soort grapjes is sindsdien, samen met de logische puzzels en het in kaart brengen van de plattegrond, een vast onderdeel geworden van text adventures. Uiteindelijk gaat het om een battle of minds, die van de maker van de adventure en die van de speler.

Eén van de eerste hoogtepunten en, net alS ADVENTURE, een legende onder de text adventures is de zo RK-serie (oorspronkelijke spel I977-I979). Het ontstaan van ZORK is een direct gevolg van ADVENTURE, zoals een van de ontwerpers, Tim Anderson, zich herinnert:

'In early I977, Adventure swept the AR PAnet. ${ }^{4 \mathrm{I}}$ (...) When Adventure arrived at MIT, the reaction was typical: after everybody spent a lot of time doing nothing but solving the game (it's estimated that Adventure set the entire computer industry back two weeks), the true lunatics began to think about how they could do it better'. ${ }^{42}$ 
In eerste instantie was zo R K een probeersel met slechts vier kamers, maar in de spanne van een aantal jaar groeide het spel uit tot een enorm complex met meer dan honderd ruimtes. Net als ADVE NTU RE werd zo R K gespeeld op een centrale computer. Inmiddels beschikten de meeste aansluitingen echter over een eenvoudig tekst-beeldscherm zodat de grotere hoeveelheid tekst die het spel produceerde geen probleem vormde.

Zo R K groeide als een olievlek. Als er iemand tijd en zin had werd er weer een deel bijgeprogrammeerd. Vaak leidde de introductie van een nieuw element, zoals dynamiet, tot andere problemen. Als het dynamiet op het verkeerde moment ontplofte, 'antwoordde' het spel dat je verpletterd werd onder twintig duizend ton rotspuin, ook al stond je midden op een groene weide. Nieuwe coderegels moesten worden toegevoegd om de logica enigszins intact te laten. Ook hier werd het een spel tussen de spelers (die telkens nieuwe creatieve manieren vonden om problemen op te lossen of objecten in het spel op niet reguliere wijze toe te passen) en de makers (die meestal snel de code aanpasten). Bij deze uitbreidingen speelden ook nu weer DUNGEONS AND DRAGONs (gevechtsregels) en The Lord of the Rings (onder andere palantir) ${ }^{43}$ een rol. Het enige nadeel van zO R K was dat het spel alleen gespeeld kon worden op de centrale computer. Aan het eind van de jaren zeventig werden er echter steeds meer homecomputers verkocht en uiteindelijk werd besloten een versie van zORK te schrijven die op deze kleine machines kon werken. ${ }^{44}$ Daarvoor moest het oorspronkelijke programma wel in delen gehakt worden, waardoor er uiteindelijk drie op elkaar volgende delen verschenen. ${ }^{45}$

ZORK was niet de eerste adventure game die na ADVENTURE werd uitgebracht. De eerste afleveringen van de serie zijn ook niet de beste text adventures die ooit uitgebracht zijn. Maar zork was wel de eerste computer adventure die commercieel succesvol was. Je zou zelfs kunnen stellen dat met zo R K de computer adventure industrie geboren is. ${ }^{46}$ Anders dan bij ADVENTU RE werden de ZO R K-spellen via reguliere kanalen verkocht, verpakt en voorzien van een handleiding. Omdat de te verkennen ruimtes complex waren en de puzzels vaak veel inventiviteit vergden, ontstond er al snel een ondersteunende service in de vorm van Movement Assistance Planners (M.A.P.s) en Hierarchical Information for Novice Treasure Seekers (H.I.N.T.s.) [sic] die op verzoek schriftelijk werden toegezonden. De gelukkige gebruikers van Usenet ${ }^{47}$ (voornamelijk studenten en medewerkers van universiteiten) konden elkaar helpen met hints en tips wanneer een puzzel te moeilijk bleek. Andere spelers moesten hun heil zoeken bij speciale hintboeken die met de groeiende populariteit van adventure games als paddestoelen uit de grond schoten. Of men kocht vakbladen. Deze computerbladen behandelden een type computer en de hard- en software, inclusief spellen, die voor dit type computer gemaakt werd. Naast hints en tips over bestaande spellen vond je in dit soort bladen, en in speciale computerboeken, ook de programmacode om zelf text adventures te programmeren. 


\section{Van tekst naar beeld, Sierra On-line en KING'S QUEST}

De komst van de thuiscomputer betekende niet alleen de geboorte van adventure games als commercieel medium, het opende ook de mogelijkheid om de spellen te voorzien van primitieve afbeeldingen. Afhankelijk van het type thuiscomputer gebeurde dit in twee, vier, acht of zestien kleuren. Omdat de computer hiervoor vaak moest omschakelen van een tekstmodus naar een beeldmodus werd in de eerste grafische adventures het spelverloop sporadisch onderbroken om een bijpassende, niet-interactieve, afbeelding te tonen. Doordat de functie van de afbeeldingen enkel illustratief en sfeerverhogend was en het aantal afbeeldingen vanwege de techniek beperkt bleef, werd de essentie van het adventure spel als interactieve literatuur hierbij niet aangetast.

De eerste adventure die tekst en beeld combineerde op één scherm was het Spel MYSTERY HOUSE uit I980, een combinatie van het spel CLUEDo en de detective Ten Little Indians van Agatha Christie. ${ }^{48}$ Myst E RY H O U E speelt zich af in een Victoriaans huis waar je je samen met zeven andere personen bevindt. In eerste instantie ben je op zoek naar een juwelenschat, maar al snel blijkt dat de andere aanwezigen een voor een vermoord worden. Aan jou de taak de moordenaar te vinden voordat hij/zij jou vindt. Het ontwerp en de tekeningen van MYSTERY HOUSE werden gemaakt door Roberta Williams, kort nadat ze in I979 zelf kennis maakte met ADVENTURE:

'I was inspired to design my first game because I had played a text-only adventure game called Colossal Cave and loved it. And - I had also played a couple of Scott Adams' text-only adventure games from a now-defunct company called Adventure International. I had loved the category of adventure game, and thought that I could do it - albeit with my own ideas and embellishments'. ${ }^{49}$

In die tijd waren er geen scanners en grafische tabletten, daarom gebruikte Roberta een soort pantograaf om de tekeningen voor het spel MYSTERY HOUSE in de computer te krijgen. Haar man Ken was verantwoordelijk voor het programmeerwerk. Om het spel onder de aandacht te brengen zette het echtpaar een advertentie in het blad Micro Magazine. De respons was overweldigend en uiteindelijk werden tachtigduizend kopieën van MYSTERY HOUSE verkocht. Hoewel MYSTE RY Hous E tekst en beeld kon combineren waren de beelden niet interactief (wel veranderde het beeld na een opdracht zoals open door). $\mathrm{Na}$ MYSTERY HOUSE maakten Roberta en Ken nog enkele andere spellen, waaronder een tweede adventure game THE WIZARD AND THE PRINCESS. Tot dan toe werden de spellen uitgebracht door Kens bedrijfje On-Line Systems. In I980 verhuisde het echtpaar echter naar het Amerikaanse Sierra gebergte en de bedrijfsnaam veranderde in Sierra On-line. 

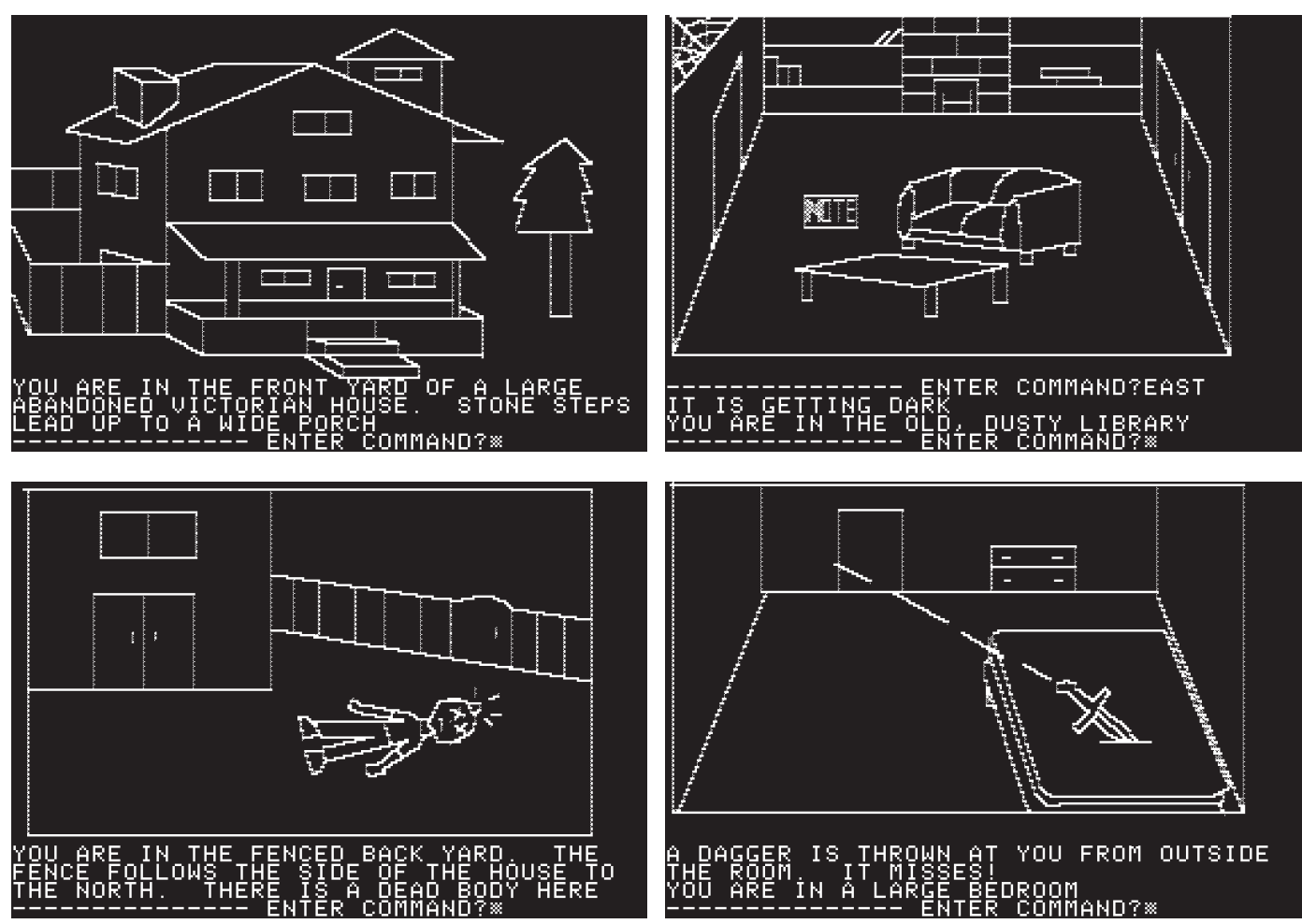

Mystery house (Roberta Q Ken Williams, 1980)

Na de primeur van MYSTE RY H Ou SE volgden er voor Roberta Williams nog vele andere $^{50}$ zoals de introductie, in I984, van de eerste tweedimensionale geanimeerde grafische adventure in de derde persoon: KING'S QUEST. KING'S QUEST werd gemaakt op verzoek van г в , die een eigen thuiscomputer op de markt wilde brengen en op zoek was naar een speciaal spel om deze computer te introduceren:

'They said, "We want something like The Wizard and the Princess, but we want to push the machine's capabilities," remembers Roberta. "I had always wanted to do animation in my games, and have more colors. Up to then the adventure games had been first-person perspective. I had the idea to do something different." So I said, "I want to create a world with a little guy running around and you control him." But if you had a little guy running around, you had to give a sense of dimensionality in the picture. He has to go behind things like trees and rocks and stuff. ${ }^{15}$

De hoofdrolspeler in KING'S QUEST I: QUEST FOR THE CROWN is de ridder Sir Graham. Je kunt hem door het spel bewegen door gebruik te maken van een joystick of van de pijltjestoetsen op het toetsenbord. De opdrachten zelf, zoals 
talk to the gnome, worden als vanouds ingetypt. En hoewel je Sir Graham nu door een tweedimensionale ruimte kunt laten lopen (waarbij de ruimtes zelf als visuele geheugensteun kunnen dienen) raadt de handleiding de speler toch aan om een plattegrond te tekenen, zoals gebruikelijk bij text adventures..$^{52}$ In deze handleiding wordt ook het verhaal verteld dat vooraf gaat aan het begin van het spel (de backstory). De KING'S QU EST-serie (nu in totaal acht spellen, waarvan de laatste in 1998 is uitgegeven $)^{53}$ voert de speler mee in een sprookjeswereld, met niet alleen koningen, prinsessen, elven en kabouters, maar ook met op sprookjes gebaseerde raadsels. Het achtergrondverhaal begint dan ook met de tekst 'A long, long time ago'. Omdat het spel ook bedoeld is voor jongere spelers is dit een goed doordacht uitgangspunt. Hoewel het eerste KING'S QUEST spel nog altijd opdrachtgestuurd is, wordt nu definitief de richting van het geanimeerde beeldverhaal ingeslagen. Door over te stappen van eerste naar derde persoon wordt de vereenzelviging met het spelkarakter in een andere context geplaatst. De speler ondergaat het avontuur niet meer zelf, het avontuur wordt gemedieerd door het spelkarakter. En de spelomgeving, die daarvoor door de speler van tekst vertaald werd in een eigen belevingswereld wordt nu geme-
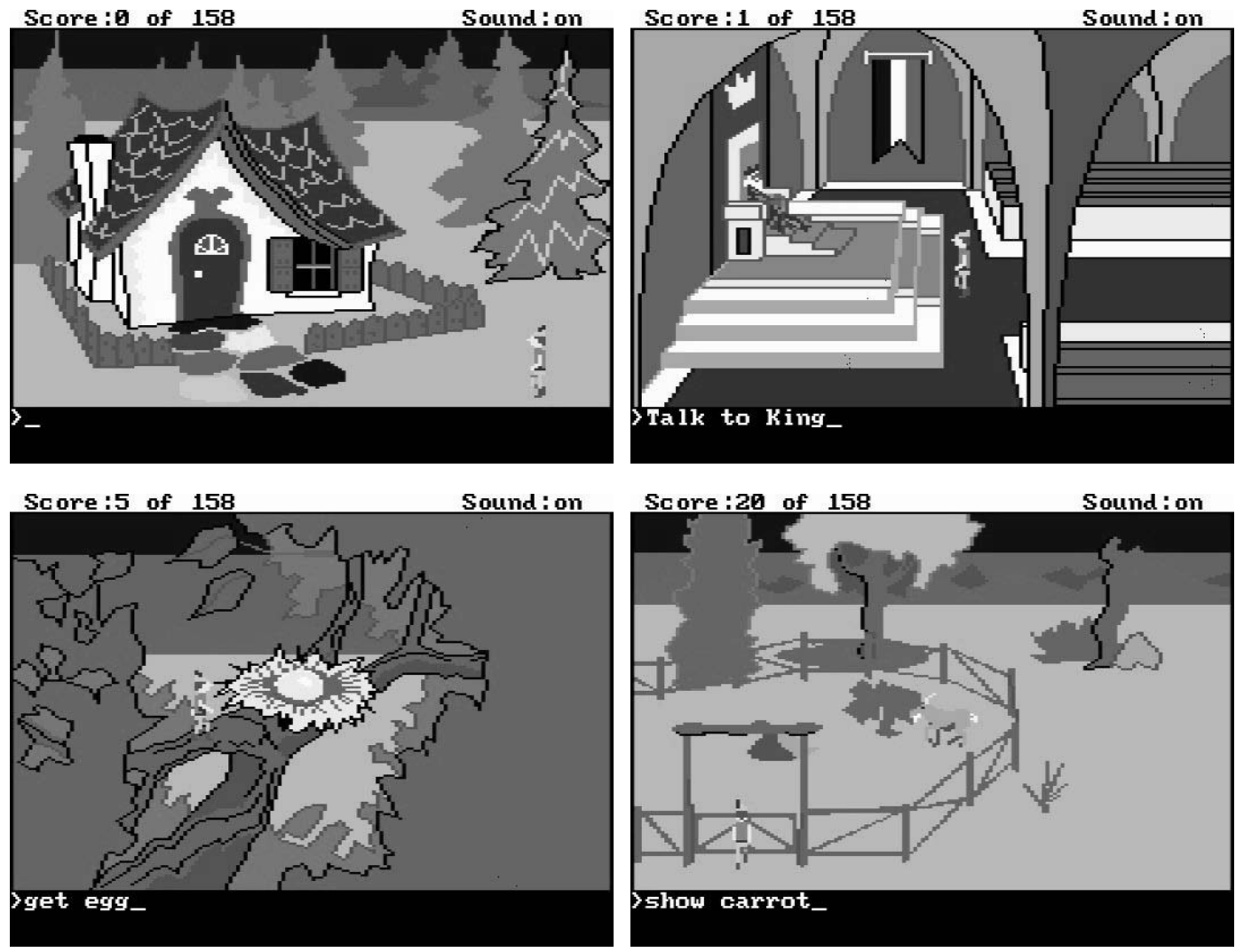

King's QUEST I: QUEST FOR THE CROWN (Sierra On-Line, 1984) 

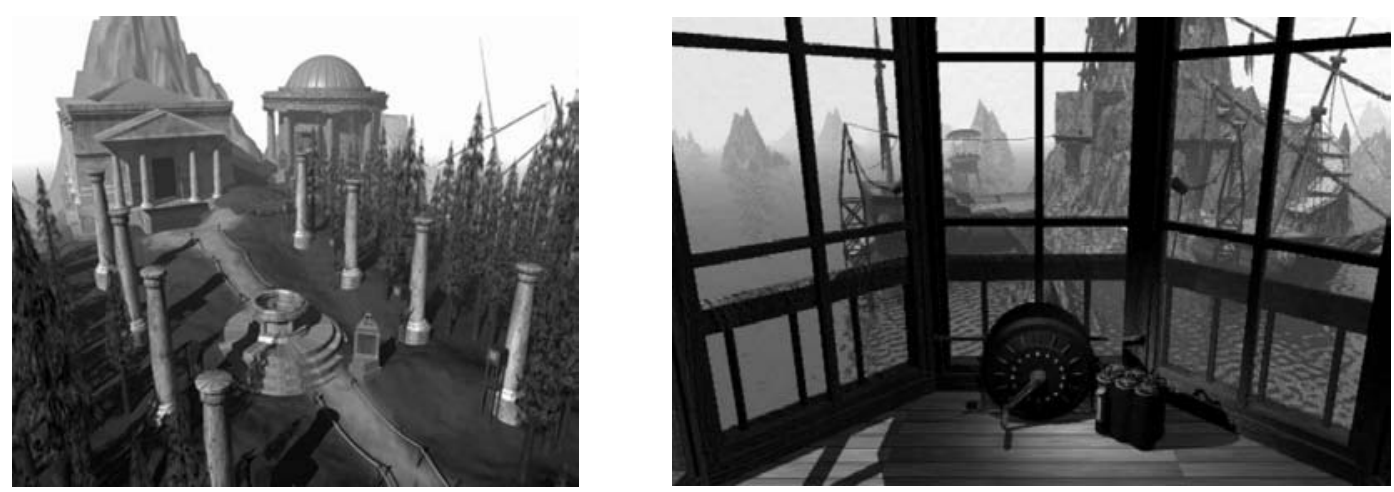

Screenshots uit MYST (Brøderbund, 1993)

dieerd door het, door de ontwerper geconceptualiseerde, beeld. Het speltype migreert daarmee naar een belevingswereld die aansluit bij de - bij de spelgeneratie passende - media film en televisie..$^{54}$

Na KING'S QUEST I heeft de ontwikkeling van de grafische adventure game niet stilgestaan. Meestal wordt deze gestuwd door nieuwe ontwikkelingen op hardware gebied. Door de introductie van muisgestuurde grafische besturingssystemen en de opkomst van de spelcomputer, verdwijnt allengs de opdrachtgestuurde invoer. Bij PC-spellen in de periode I990-I995 vindt de interactie vrijwel uitsluitend met behulp van de muis plaats waarbij de mogelijkheden van de speler ingeperkt worden omdat enkel nog gekozen kan worden uit een beperkt aantal varianten. Hierdoor krijgt de adventure het karakter van een interactieve strip. Door verbeterde grafische mogelijkheden krijgen de spellen een natuurlijker kleurpalet en een hogere resolutie. Door de komst van de geluidskaart en de CD-Rom wordt het ook mogelijk de rollen in het spel door acteurs in te laten spreken, waardoor het voor de spelers lijkt alsof ze deelnemen aan een interactieve tekenfilm. Door de grote opslagcapaciteit van de CD-Rom en nieuwe grafische mogelijkheden kunnen de afbeeldingen nog fotorealistischer worden, zoals in het spel mysт (Brøderbund, I993). Myst met de ondertitel 'The surrealistic adventure that will become your world,' valt niet alleen op door de prachtige beelden, het spel grijpt in spelopzet direct terug naar de adventures van het eerste uur: de speler speelt weer in ik-vorm maar moet nu zijn of haar weg vinden in een labyrint van surrealistische beelden. Dit en het niet-gewelddadige karakter van het spel maken het tot de computerhit van I994 en de daaropvolgende jaren. In I998 was MYST zelfs het best verkochte spel ooit. ${ }^{55}$ Voor de computerspellenindustrie was MYST ook een keerpunt. De hyperrealistische beelden zetten niet alleen nieuwe standaarden voor andere spellen (ook nietadventure games), de demografische spreiding van de spelers (waaronder veel vrouwen en senioren) liet zien dat de computerspellenmarkt niet alleen bestond uit jongetjes van tien tot vijftien jaar. 
De periode I994-I995 is ook de tijd dat de eerste adventures uitkomen die gebruik maken van full motion video, zodat het nu interactieve films lijken. Full motion video is echter behoorlijk beperkend voor de interactie. Alleen scènes die van tevoren opgenomen zijn kunnen worden gebruikt en aangezien dit niet alleen erg kostbaar is, maar ook bijzonder veel diskruimte vergt (spellen van zes of acht CD-Roms zijn eerder regel dan uitzondering) is het aantal puzzels en mogelijke oplossingen uiteindelijk minder groot dan in een tweedimensionaal spel. Toch zijn er enkele spellen uit deze tijd, zoals UNDER A KILLING MOON (Access Software, I994) die uitblinken door hun interactieve verhaallijn en de vele puzzels. Het gebruik van full motion video is niet de enige reden waarom deze spellen sterk aan films doen denken; de gebruikte genres (zoals detective en court drama) zijn regelrecht van de (tv)film overgenomen en er wordt vaak en veelvuldig geciteerd. Hoewel full motion video erg populair is, is de gebruikte techniek te restrictief in de ogen van de spelers. Daarom stapten de makers van adventure games uiteindelijk ook over op driedimensionale graphics, zoals al gebruikt in andere typen spellen als D o o M (id Software I993), ${ }^{56}$ waarbij de beelden real time tijdens het spelen gegenereerd worden en de speler meer vrijheid van handelen krijgt. ${ }^{57}$ Tegenwoordig is de rekenkracht van PC's dusdanig toegenomen dat de real time gegenereerde beelden steeds gedetailleerder worden zodat het onderscheid tussen werkelijkheid en verbeelding uiteindelijk niet meer waarneembaar zal zijn. Omdat de handeling dan niet meer van te voren vast hoeft te liggen zullen toekomstige adventure spellen op veel meer situaties logisch kunnen reageren waardoor zij weer de verhaaldiepte bereiken van spellen als zORK.

\section{Het verlangen naar de Middeleeuwen}

Umberto Eco constateert in de tweede helft van de twintigste eeuw een duidelijke hang naar de Middeleeuwen, met name in de populaire cultuur:

'We are at present witnessing, both in Europe and America, a period of renewed interest in the Middle Ages, with a curious oscillation between fantastic neomedievalism and responsible philological examination. ${ }^{58}$

Maar om welke Middeleeuwen gaat het hierbij? Zoals Eco al aangeeft is het beeld dat wij in de twintigste eeuw van de Middeleeuwen hebben geen accurate weergave (voor zover dat al mogelijk is), maar een modern construct, zeker waar het gemedieerd wordt door de massamedia. In Engeland werd dit beeld in de negentiende eeuw al gevormd door de romans van Walter Scott en William Morris, de kunstwerken van de prerafaëlieten en de neogotiek. In de twintigste eeuw is het het werk van Tolkien en C.S. Lewis dat de Middeleeuwen gestalte geeft, niet alleen door middel van hun academische studies (voor Lewis middeleeuwse 
literatuur en voor Tolkien middeleeuwse gedichten) maar vooral ook door hun populaire literaire werken. Of zoals Norman F. Cantor het verwoordt: 'In terms of shaping the Middle Ages in the popular culture of the twentieth century, Tolkien and Lewis have had an incalculable effect'. ${ }^{59}$ Toch is het beeld van de Middeleeuwen dat Tolkien schetst in The Lord of the Rings historisch gezien vrij accuraat. Dit is te danken aan Tolkiens uitgebreide kennis van en grote liefde voor die periode. Voor wie bekend is met Oud-Noorse en Angelsaksische literatuur is het duidelijk dat Tolkien, zoals hij het zelf zegt, '[wrote] a modern work in the same [medieval] tradition'. ${ }^{60}$ Daarmee is The Lord of the Rings 'a modern reconstruction of a fragment of medieval culture'. ${ }^{6 \mathrm{I}}$ Dit is bijvoorbeeld zichtbaar in het reisgezelschap dat uit Rivendell vertrekt. Hoewel de metgezellen uit verschillende 'rassen' (mens, elf, dwerg, hobbit, magiër) bestaan, vertegenwoordigen ze de drie hoofdklassen van de middeleeuwse cultuur: de adel (Aragorn, Boromir, Legolas en Gimli) wiens taak het is door middel van krijgskunst het land en de burgers te verdedigen; de burgerij (de hobbits) die het land bewerken en voedsel produceren; en de geestelijkheid (Gandalf, uiteraard niet letterlijk) die voor het bovennatuurlijke verantwoordelijk is. In Tolkiens wereld komt dit onderscheid niet alleen tot uitdrukking in hun handelingen, maar ook en vooral in de door hen gebruikte taal. Natuurlijk zijn er binnen de klassen ook rangen en standen (Frodo is van een hogere sociale afkomst dan Merry en Pippin), maar in principe blijven de karakters fungeren binnen de klasse waartoe ze behoren. Deze indeling in rassen en klassen is overgenomen in het spel DU NGEONS AN D DRAGONS, niet alleen vanuit The Lord of the Rings maar ook omdat het oorspronkelijke Kriegspiel, Gygax' CASTLE AN D CRU SADE SOC I ETY, hier al deels vanuit ging. Vanuit DUNGEONS AND DRAGONS is deze indeling overgebracht naar de moderne (Massively Multiplayer) Role Playing Games. Iemand die nu dus meespeelt in het populaire medieval fantasy M M R PG EVERQUEST (989 Studios, eerste versie I999) beweegt zich dus nog altijd in een uit de Middeleeuwen voortkomende ordening. Ofschoon de karakterordening in deze spellen voortkomt uit die periode, is de setting waarin de verhalen zich afspelen duidelijk een geromantiseerd beeld van de Middeleeuwen, ongetwijfeld voortgekomen uit de gemedieerde versies uit de schilderkunst, de strip en de film.

Uiteraard zijn er wel spellen met een meer realistische weergave, maar deze zijn meestal educatief. Een recente uitzondering is het spel MICHAEL CHRICHTON TIMELINE (Eidos Interactive, 2000), dat gepromoot werd met de slogan 'the Future of Adventure is a journey into the past...'. Net als in het gelijknamige boek, gaat het om een fictief verhaal van een archeologisch team dat terugkeert in de Middeleeuwen. In het boek zijn de handelingen echter gebaseerd op archeologische vondsten en recent historisch onderzoek. In het spel moesten de makers, naar eigen zeggen, het midden vinden tussen 'historical accuracy and artistic vision needed to meet the requirements'. ${ }^{62}$ Hierdoor kan het spel, net als de gelijknamige film uit 2003, niet tippen aan het boek. Maar de concessies aan de technische (on)mogelijkheden zijn niet de enige reden dat het 


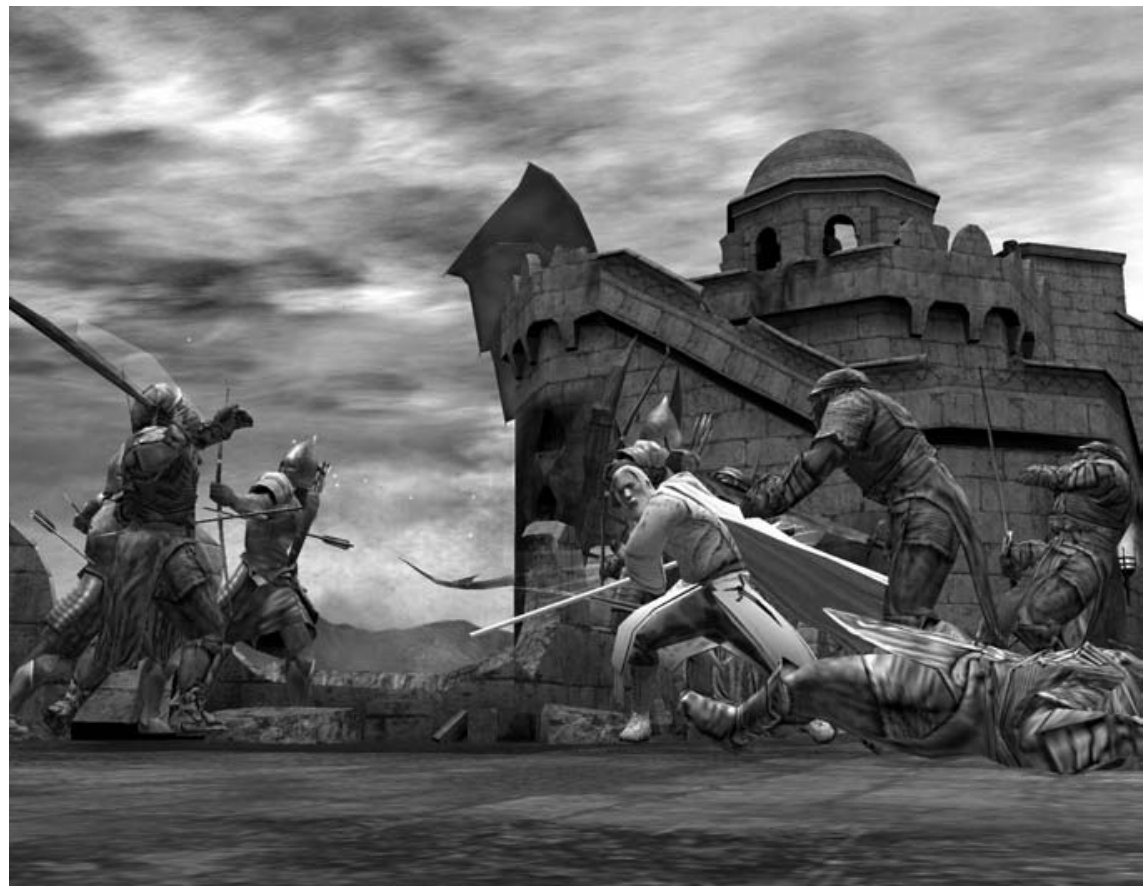

Screenshot uit THE LORD OF THE RINGS. THE RETURN OF THE KING (Electronic Arts, 2003)

spel geflopt is. Net als de CASTLE AND CRUSADE SOCIETY blijkt ook hier dat een meer op de realiteit gebaseerde historische voorstelling van de Middeleeuwen voor de huidige generatie spelers niet spannend of interactief genoeg is.

De hang naar de Middeleeuwen die we met name in adventure en (M M)R PG spellen zien is niet een fenomeen dat specifiek is voor het computerspel. In zijn boek Strange Landscapes ${ }^{63}$ constateert Christopher Frayling dat de interesse voor de Middeleeuwen zich uitspreidt van (populaire) literatuur, beeldende kunst, het stripboek en de film tot en met muziekstromingen als Heavy Metal. Het is niet meer dan logisch dat deze trend zich ook voordoet in de computerspellenindustrie, momenteel de snelst groeiende tak van de entertainmentindustrie. Maar net als in de andere media gaat het om een geïnterpreteerde versie van de Middeleeuwen.

\section{Conclusie}

Het moderne adventure spel vindt zijn oorsprong in het werk van J.R.R. Tolkien en het rollenspel DU NG EON S AN D DRAG ON S. Maar waar in het werk van Tolkien sprake is van een gereconstrueerde middeleeuwse cultuur is de moderne adventure gamer niet geïnteresseerd in een historisch accurate belevenis. Net als in het verleden heeft ook deze (game-)generatie Tolkiens werk op eigen wijze geïnterpreteerd. Dit is duidelijk te zien aan de huidige Lord of the Rings spellen. Vooral de 
spellen die afgeleid zijn van de films van Peter Jackson, THE LORD OF THE RINGS, THE TWO TOWERS (Electronic Arts, 2002) en THE LORD OF THE RINGS, THE RETURN OF THE KING (Electronic Arts, 2003), zijn in grote aantallen, zowel voor de PC als de spelcomputer gekocht. In deze spellen ligt de nadruk niet op het verhaal (dat iedereen immers kent van de films [sic]) maar op de actie. En zoals mijn generatie op het speelplein er lustig op los hakte als Ivanhoe of Floris bestuurt de huidige generatie Aragorn, Legolas of Gimli terwijl hordes Orcs aanvallen.

In vergelijking met deze goed grossierende actiespellen stelt het, op denkwerk gebaseerde, adventure speltype niet veel meer voor. Voor de vrouwelijke speler - die in dit speltype altijd goed vertegenwoordigd was - zijn er tegenwoordig andere spellen die vooral draaien om sociale interactie, zoals de zeer populaire s I M S-serie (2000-2004). Toch ziet gamespecialist Steven Poole nog wel een toekomst voor de klassieke adventure game. Een toekomst waarin de beperkte keuze opgelegd door de muis of de joystick vervangen wordt door spraakgestuurde opdrachten. In combinatie met de, dan nog sneller gerealiseerde, hyperrealistische realtime graphics kan het adventure game zich dan weer focussen op het element waar het in uitblinkt, een fantastisch verhaal:

'But I suppose it's often that way. The brave things in the old tales and songs, Mr. Frodo: adventures as I used to call them. I used to think that they where things the wonderful folk of the stories went out and looked for, because they wanted them, because they were exciting and life was a bit dull, a kind of sport, as you might say. But that is not the way of it with the tales that really mattered, or the ones that stay in the mind, ${ }^{64}$

\section{Noten}

I R.H. \& R.M. Seymour, 'A Mappa Mundi for the new millennium', Proceedings of the Eighth International Coral Reef Symposium, 2, I997, p. I357.

2 Ik geef er de voorkeur aan te spreken van typen computerspellen in plaats van genres om de verwarring met filmgenres te vermijden.

3 In Nederland worden deze computers, zoals de Commodore 64, de Spectrum zx, de в вс microcomputer, de Atari st en de Amiga meestal aangeduid met de term home computer of thuiscomputer. De term microcomputer werd ook vaak gebruikt voor zowel deze computers als de eerste PC's.

4 De eerste echte adventure game die op een arcadekast gespeeld werd was D RAG ON'S LAIR van Cinematronic, uitgebracht in I983. Zie het artikel van René Glas in dit nummer.

5 In zijn artikel 'Games Telling Stories' dat verschenen is in de eerste uitgave (juli 200I) van het International Journal of Game Research beargumenteert Juul dat interactiviteit en narrativiteit niet samen kunnen gaan. Daarmee concludeert hij dus feitelijk dat interactieve verhalen geen computergames in zijn definitie van deze term kunnen zijn. Alleen online beschikbaar op: http://www. gamestudies.org/oroI/juul-gts/.

6 Ik beperk me tot de PC omdat informatie over de geschiedenis van adventure games die op spelcomputers gespeeld worden eenvoudig te vinden is in overzichten, zoals Steven L. Kent, The Ultimate History of Video Games, Roseville 200 I en R. DeMaria \& J.L. Wilson, High Score!, the illustrated history of electronic games, Berkeley 2002. 
7 Met de uitbreiding van de 3D grafische mogelijkheden van de personal computer eind jaren negentig is er een grote hausse ontstaan van Real Time Strategy Games (RTS), een speltype dat gebaseerd is op het naspelen van historische veldslagen met behulp van tinnen soldaten en dat in de jaren tachtig als bordspel erg populair was, zoals het bekende spel civilization. Real Time Strategy Games spelen zich ook vaak af in historische settings.

8 Definitie 'Jeu d'aventure’ Wikipédia, zie http://fr.wikipedia.org/wiki/Jeu_d\%27aventure.

9 Dit is de oorspronkelijke term. Toen er naast multi-user spellen ook virtuele gemeenschappen ontstonden, is dit veranderd in Multi User Domains. Voor spellen wordt echter nog altijd Multi User Dungeon gebruikt.

Io Dit type adventure spel werd al eerder geïntroduceerd op de spelcomputer. Eén van de bekendste en meest invloedrijke action adventure series op de spelcomputer is de LEGEND OF ZELDAserie van Shigeru Miyamoto, waarvan het eerste spel in I986 uitkwam. Op de microcomputer werd dit speltype overigens al in I989 geïntroduceerd met het spel PRINCE OF PERSIa (Brøderbund).

II T. Pratchett in: J. Birkett (production \& direction) J.R.R. TOLKIEN MASTER OF MIDDLE EARTH, ввС омNiвUs, B. Comely (series ed.), ввС 200 .

I2 J. Hacking, 'Introduction' in: L. Hawksley, Essential Pre-Raphaelites, Bath I999, p. 6 e.v.

I3 W. Morris, 'Introduction' in: The Volsunga Saga, I870. Elektronische versie http://sunsite. berkeley.edu/omavL/Volsunga/introduction.html.

I4 Tolkien werd als kind door zijn moeder onder meer voorgelezen uit het Red Fairy Book van Andrew Lang, waarin het verhaal van Sigurd was opgenomen. Over dit verhaal schreef zijn biograaf: 'It was the best story that he had ever read'. H. Carpenter, J.R.R. Tolkien: a Biography, Suffolk I977, p. 39 .

I5 Carpenter, Tolkien, p. 99.

I6 Uit een brief die Tolkien schreef aan Milton Waldman in I95I. H. Carpenter (ed.), The Letters of J.R.R. Tolkien, New York I995, p. I44.

I7 T. Shippey, J.R.R. Tolkien, Author of the Century, New York 2000, p. xv.

I8 In The Hero with a Thousand Faces (I949) toont Joseph Campbell aan dat de mythe van de held in vrijwel elke, ook niet-westerse, mythologie voorkomt en dat er dus sprake is van een archetypische held. Hiermee toont hij aan dat Tolkien met zijn idee van oermythen op het goede spoor zat. Aragorn uit The Lord of the Rings, gebaseerd op Sigurd uit de Volsunga Saga, is een van Tolkiens reconstructies van de mythische held.

I9 H. Carpenter in: J. Birkett (production \& direction) J.R.R. TOLKIEN MASTER OF MIDDLE EARTH, ввС OMNiBUs, B. Comely (series ed.), ввС 200 I.

20 I. Livingstone in: J. Birkett (production \& direction) J.R.R. TOLKIEN MASTER OF MIDDLE EARTH, ввС OмNiBUs, B. Comely (series ed.), ввС 200 I.

2I Het eerste spel u ltima verscheen in I98I bij California Pacific Computer. Daarna verschenen nog negen single-player spellen. In I997 verscheen de eerste online versie ULTIMA ONLINE (Electronic Arts Inc.), in 2002 gevolgd door ULTIMA ONLINE: LORD BLACKTHORN'S REVENGE (Electronic Arts).

22 R. DeMaria en J.L. Wilson, 'Richard Garriot \& Origin Systems' in: High Score! the Illustrated History of Electronic Games, Berkely 2002, p. II8.

23 Wizards of the Coast, inc., Adventure Game Book Adventure 1: Rescue the Unicorn, Renton 2000 , p. 2.

24 'A game in which players take on the roles of imaginary characters, usually in a setting created by a referee, and thereby vicariously experience the imagined adventures of these characters', Oxford English Dictionary.

25 Zie http://zeitcom.com/majgen/98lwars.html voor de oorspronkelijke omslag en http:// www.miniaturewargaming.com/2004/06/hg_wells_little.html voor een online versie.

26 Hoewel er enkele leden van buiten Amerika deelnamen bestond het grootste deel van het ledenbestand uit deelnemers uit het Amerikaanse Midwesten. De IFw bestaat nog.

27 B.E. Sones, 'Here There Be Dragons, into the past and future of role-playing games', in: Computer Games Online, december 20oI. Zie http://www.cgonline.com/features/oII2I8-fI-fI.html voor de elektronische versie. 
28 De invloed van Tolkien blijkt uit de oorspronkelijke regels van het spel waar het ras Hobbit in voorkwam totdat na een juridisch gevecht met erfgenamen van Tolkien dit verboden was. Gygax heeft daarna de invloed van Tolkien op zijn werk altijd onderbelicht. Zie A. DeVarque, Literary Sources of Dungeons and Dragons, elektronische versie http://www.geocities.com/rgfdfaq/sources. html.

29 Het spel werd pas in 1974 voor het eerst officieel onder deze naam op de markt gebracht.

30 Hierbij doel ik niet op de (bijzonder slechte) fantasy film met gelijknamige titel, maar films etc. waarin het spel zelf gespeeld wordt.

3I Deze film is gebaseerd op het gelijknamige boek van Rona Jaffe: Mazes and Monsters, New York i98I.

32 In sommige versies van dit verhaal is er sprake van een jaar.

33 Dat de publieke opinie over spellen als DUNGEONS AND DRAGONS in de tussentijd veranderd is, is te zien in de film THE CH RON ICLES OF RIDDICK (Universal Studios 2004). Hierin wordt ook het spel D\&D gespeeld met de hoofdrolspeler Vin Diesel als dungeon master en Dame Judy Dench als één van de deelnemers, alleen is de boodschap nu positief: als je DUNGEONS AND DRAGons speelt, ben je cool.

34 Een uitgebreide geschiedenis van ADVENTURE is te vinden op http://www.rickadams.org/ adventure/a_history.html. Informatie over computerprogramma's die adventure-achtige elementen bevatten en voor ADVENTURE gemaakt werden, zie Graham Nelson, 'A short history of interactive fiction' in: Inform Designer's Guide, 200I, \46. Elektronische versie: http://www.informfiction.org/manual/html/s46.html.

35 Idem.

36 De term 'natuurlijke taal' moet hier niet te letterlijk genomen worden, maar gezien worden in het licht van de tijd. Adventu RE werkte in de oorspronkelijke versie met twee woorden in de vorm actie - object, bijvoorbeeld 'Take Key'.

37 Omdat Amerikaanse geologen onderaardse ruimten (of het nu grotten of andere ruimten zijn) aanduiden met de term 'room' bestaat een adventure game tegenwoordig ook nog altijd uit 'rooms', ook al wordt een ruimte in de open lucht beschreven.

38 Op de website http://www.rickadams.org/adventure/e_downloads.html zijn speelbare versies (waaronder een versie voor Windows, die echter niet werkt met Windows NT of XP) van ADVENTU RE te downloaden. Woods en anderen hebben de oorspronkelijke versie meer dan een keer aangepast, uitgebreid en veranderd (met andere maximale scores). Met dank aan internet en Java kan het oorspronkelijke spel nu ook online gespeeld worden op: http://plugh.xyzzy.net/xyzzy.html. Deze versie lijkt nog heel erg op de eerste aangepaste versie van Woods.

39 Dit had ook te maken met de beperkte in- en uitvoermogelijkheden. In latere versies is het wel mogelijk om instructies te krijgen.

40 Het in kaart brengen van ADVE NTU RE was nog behoorlijk lastig. Enerzijds omdat je te maken kreeg met verschillende niveaus, anderzijds omdat er allerlei geheime doorgangen waren die je met raadselachtige codes, zoals xyzzy, direct naar een ander deel van het spel konden transporteren.

4I ARPAnet is de voorloper van internet. Oorspronkelijk waren op het AR PAnet alleen computers aangesloten van de Amerikaanse defensie en van universiteiten en onderzoekslaboratoria die voor defensie werkten.

42 Tim Anderson, The New Zork Times, vol. 4, nr I, winter I985. Elektronische versie: http:// www.csd.uwo.ca/Infocom/Articles/NZT/zorkhist.html.

43 Idem.

44 In die tijd hadden homecomputers vaak niet meer geheugencapaciteit dan $\mathrm{I} 6 \mathrm{~K}$ bytes (waarin dus maximaal $\mathrm{I} 6.000$ tekstkarakters passen, bestaande uit zowel het programma als de data). Zork op de centrale computer was I м в (I.024 K bytes) groot.

45 De eerste drie delen zork I, zork II en zork III kunnen nu worden gedownload via de site http://www.csd.uwo.ca/Infocom/.

46 De microcomputer-industrie bestond uit modellen van uiteenlopende fabrikanten (Apple, Commodore, Tandy, Atari, Acorn. Sinclair, г в м, om de bekendste te noemen) die onderling niet compatibel waren. Om een programma succesvol uit te brengen moest er een versie voor de meest 
verkochte merken en typen gemaakt worden. Voor text adventures was deze operatie eenvoudiger dan voor grafische spellen. Een van de redenen waarom zork een commercieel succes was en legendarisch geworden is, is dat het spel voor vrijwel elk merk en type computer werd uitgebracht.

47 Usenet zou je toentertijd de universitaire tegenhanger van AR PAnet kunnen noemen. Via de dienst Usenet News konden de gebruikers van dit netwerk informatie uitwisselen. News fungeerde daarbij als een groot prikbord dat ingedeeld was in aparte categorieën, de nieuwsgroepen. Usenet bestaat nog altijd en is nog steeds een goede uitwisselingsbron voor hints en tips bij het spelen van games.

48 Het originele spel kan gratis worden gedownload van http://www.sierraplanet.com/ mysteryhouse.

49 K. Wright \& A. Marold, 'Game Goddess Roberta Williams', in: Woman Gamers. Com Articles, mei 2000. Elektronische versie: http://www.womengamers.com/interviews/roberta.html.

50 Door het fenomeen Lara Croft uit TO M B RAIDER lijkt het alsof er voor die tijd geen vrouwelijke hoofdrolspelers in adventure games bestonden. Volgens Justine Kessel en Henry Jenkins in From Barbie to Mortall Kombat, Cambridge Massachusetts 2000, p. 9, was Rosella, de hoofdrolspeelster in KING'S QUEST IV: THE PERILS OF ROSELLA [sic] uit het jaar I 988 de eerste female lead in een computerspel, hoewel er toch enige zorg bestond dat het mannelijke deel van de gamers zou afhaken.

5I DeMaria \& Wilson, High Score!, p. I38.

52 Plattegronden zijn niet alleen handig om niet te verdwalen. De meeste adventure spelers gebruiken ze ook om aan te geven waar een bepaald object of persoon gevonden kan worden.

53 De KING'S QUEST serie kent nog altijd een grote schare trouwe fans. Een aantal van hen heeft KING'S QUEST I herschreven naar een muisgestuurde versie met een betere beeldkwaliteit en gesproken dialogen (zoals de latere versies van KING'S QU EST). Het spel kann gratis worden gedownload van de site http://www.agdinteractive.com/.

54 De text adventure is hiermee niet uitgestorven, er bestaat nog altijd een trouwe schare fans die zelf nieuwe avonturen creëert, terwijl de klassiekers telkens weer vertaald worden naar versies die op de huidige generatie PC's of internet speelbaar zijn. Tekstuele role playing adventure games (Multi User Dungeons) zijn zelfs, door de komst van internet, bijzonder populair.

55 Volgens de gegevens van PCData (nu N D P Market Tracking).

56 Doom grijpt qua spelopzet in feite ook weer terug op de adventure spellen van het eerste uur: dwalen door een labyrint met gevaar voor eigen leven. Alleen ligt nu de nadruk op overleven, waardoor het verhaal minder belangrijk wordt.

57 In 3D spellen komen ook vooraf gerenderde cut scenes voor die meestal delen van de backstory vertellen of die twee verhaaldelen logisch met elkaar verbinden. Doordat deze stukken vooraf gemaakt kunnen worden op zware grafische computers tonen ze bijzonder realistisch.

58 U. Eco, 'Dreaming the Middle Ages', in: W. Weaver (vert.) Travels in Hyperreality, origineel I973, deze versie New York I986, p. 63.

59 N.F. Cantor, Inventing the Middle Ages, the Lives Works and Ideas of the Great Medievalists of the Twentieth Century, New York I99I, p. 208.

6o Idem, p. 227.

Gi Idem.

62 Tekst uit de handleiding van het spel.

63 C. Frayling, Strange Landscapes: a journey through the Middle Ages, London I995, pp. 7-36.

64 J.R.R. Tolkien, The Lord of the Rings: the Two Towers, London 2de druk I974, p. 285. 